\title{
Rural Household Income: Who's Educational Attainment Counts?
}

\author{
Ojide Kelechi Charity $^{1}$, Ojide Makuachukwu Gabriel ${ }^{2 *}{ }^{\mathbb{C}}$, Ogbodo Joseph $^{3}$
}

\author{
${ }^{1}$ Department of Mathematics/Computer Science/Statistics/Informatics, Alex Ekwueme Federal University Ndufu-Alike, Ebonyi State, \\ Nigeria \\ ${ }^{2}$ Department of Economics and Development Studies, Faculty of Management and Social Sciences, Alex Ekwueme Federal \\ University Ndufu-Alike, Ebonyi State, Nigeria \\ ${ }^{3}$ Economics Department, Faculty of Social Sciences, Enugu State University of Science and Technology, Enugu State, Nigeria \\ E-mail: embracegod1@yahoo.com
}

Received: 21 August 2020; Revised: 25 February 2021; Accepted: 25 February 2021

\begin{abstract}
Many factors contribute to household income; The key among them is education. This paper seeks to ascertain if there is any difference between the effect of education attainment of the household head and that of the most educated member of the household on household income. The study used data from 400 rural households in Ogoni, Rivers State, Nigeria, selected by a stratified random sample. The data were analyzed using mean difference test and ordinal logistic models. The paper established evidence supporting positive influence of education on household income $(\mathrm{p}<0.01)$. Two methodological conclusions were drawn. First, either education attainment of the household head or education attainment of the most educated member of the household can be used to estimate the influence of education on household income even when the distribution of these two exogenous variables are significantly different. Second, both exogenous variables should not be used together in the same household income function to avoid biased estimates due to collinearity. A major limitation of this study is recommended for further study. That is, the questionnaire used in the study did not provide information on how many household heads are the most educated members of their respective households. The possible endogeneity bias in such situation should be captured in future estimation. The study concludes that improving education attainment of, at least, a household member could be an effective way of increasing household income in rural communities.
\end{abstract}

Keywords: community, poverty, well-being, rural areas, education, income

JEL Codes: A11, A20, C01, C21, C80, D14, H31

\section{Introduction}

There are several economic benefits of education. One of such benefits is the opportunity to secure paid employment or acquire skills to earn income through self-employment (that is, working for oneself rather than for an employer). As a result, enhancing education attainment (that is, improving on the highest degree of education citizens can accomplish) has been a crucial part of development strategies of most countries. Virtually all governments in developing and developed countries consider raising the education attainments of their citizens as a major strategy towards human capital development. The relationship between education attainment and income is strong. Generally,

\footnotetext{
Copyright (C2021 Ojide Makuachukwu Gabriel, et al.

DOI: https://doi.org/10.37256/redr.212021599

This is an open-access article distributed under a CC BY license

(Creative Commons Attribution 4.0 International License)

https://creativecommons.org/licenses/by/4.0/
} 
education is referred to as human capital investment. Investment in human capital is often driven by similar reasons people invest in financial assets which includes to make money. Human capital, in this context, refers to knowledge and skills (that is, ability to deliver on a given task) obtainable through education, training, and experience. Generally, the more skills people acquire, the more employable they become. Similarly, the relationship between education attainment and wealth is strong. Obviously, earning a higher income enhances savings, and savings are essential to build wealth. Low income earners have a flatter income pattern which makes savings more difficult (Wolla \& Sullivan, 2017).

Literally, hundreds of studies have uniformly provided evidence that more schooling is associated with higher income earning at national, household and individual levels (Leigh \& Ryan, 2008; Blanden et al., 2012; Devereux \& Fan, 2011; Park, 2011; Ganegodage \& Rambaldi, 2011; de Baldini et al., 2011; Hanushek, 2013). The rate of return to education attainment in most countries is approximately 10 percent with different degrees of variations (Hanushek \& Wößmann, 2007). Other empirical studies have also demonstrated that higher education attainment increases the probability of employment (Tsai et al., 2009; Dickson \& Smith, 2011; de Baldini et al., 2011; Frank \& Tobias, 2013). Study by Nelson and Phelps (1966) points out that education attainment enhances one's capability to receive, interpret, and understand new information. Little wonder, most studies on household income treat education attainment as a key factor (Hanushek \& Wößmann, 2007; Bourguignon, 2005). According to Roberts (1988), one of the major factors influencing a country's standard of living is the extent to which it succeeds in developing and utilizing knowledge and skills, and improving the education and health of the majority of its population.

Consequently, earning returns to education attainment has perhaps been one of the predominant areas of research interest in economics of education for over 50 years (Leigh \& Ryan, 2008; Dickson \& Harmon, 2011; Devereux \& Fan, 2011; Dickson \& Smith, 2011; Park, 2011; Ganegodage \& Rambaldi, 2011; Blanden et al., 2012; Evan, Günther et al., 2015). However, in studies on household earning returns to education, only little interest has been shown on whose educational attainment actually drives increase in household income. For instance, in the studies of Babatunde (2008); Ibekwe (2010); and Fadipe, Adenuga and Lawal (2014) on the effect of education attainment on household income, only the education attainment of household heads were considered. Similarly, in other studies aside Nigeria such as Jehovaness (2010) in Tanzania, and Tuyen (2015) and Van Vu (2020) both in Vietnam, only the education attainment of household head was considered in the study of socio-economic determinants of household income. Even in most related studies like the effect of education on household poverty level (Wanka \& Rena, 2019) and the effect of education on household farming activities (Wanka, 2014), the education attainment of household heads is often used without reference to the education attainment of the most educated member of the household. Furthermore, Jamison and Lau's (1982) review of the literature on household farm income in relation to schooling, as cited in Jolliffe (1997), examined the results of more than 35 studies from Latin America, Asia, and Africa. With the exception of 1,904 Korean farm households discussed in Jamison and Lau (1982), these studies clearly assume that it is only the education attainment of the household head that influences farm income and that the education attainment of all other household members have no effect.

However, Jolliffe (1997) compared the head-of-household (education attainment) model to three competing models (which are: household maximum schooling, household average schooling, and household minimum schooling) and concludes that the average or the maximum level of education in the household is a significant determinant of household income. Weir (1999) agrees that in modeling education attainment in household-level income functions, several different measures of education may be used. In such household-level income functions, education could be measured as school attainment of the household head alone, average school attainment of all adult household members, average school attainment of all non-head adult household members, or school attainment of the most educated adult household member.

This current study, therefore, seeks to contribute to existing literature on the role of education attainment in enhancing household income by considering the effects of education attainment of the household head and that of the most educated member of the household on household income. It also considers the effect of including education attainment of household head and that of the most educated member of the household in the same household-level income function. 


\section{Review of literature}

The concept of the rate of return on education is similar to any other form of investment. It is based on human capital theory and signalling theory which stipulate that investment in education increase future productivity. Estimation of returns on education investment has been a prevalent subject in literature. Several studies have sought to explain the earnings-gap between the less-educated and the more-educated in different economies. The relationship between returns to education and earnings inequality has led to speculation among many economists, policymakers and development partners that increasing educational attainment, especially among the poor, could help reduce earning inequality. However, the flipside of the augment is that an increase in the proportion of the highly educated will most likely decrease the general returns to education through supply-side factors. In any case, education is basically linked to participation in labour force with evidence that more educated people are generally more likely to secure lucrative jobs available in the labour market (Psacharopoulos \& Patrinos, 2018; Bartik et al., 2018). Education, in this context, is not the learning of facts; it is rather the training of the mind to think and act in a more productive manner.

The human capital theory establishes a linkage between poverty and education with reference to education as a means to poverty reduction. It stipulates that investment in education results in the creation of skills which enhances productivity and improves the chances of securing employment and higher income earning in future. Empirical studies also have show strong relationship between educational levels and workers' wage. An alternative explanation to the positive linkage between earnings and education is the signalling theory. The theory explains that individuals often use their education attainment to signal broad sets of essential productive skills or aptitudes that are not easily identified by employers. In other words, education attainment signals the existence of human capital which gives individuals advantage in labour force participation (Wanka, 2014).

Many empirical analyses from a wide variety of economies, including longitudinal evidence, and estimates based on new econometric analytical techniques, reaffirm the importance of human capital and signalling theories (Psacharopoulos \& Patrinos, 2018). For instance, a study on return to education and financial value of investment in higher education in Indonesia indicates that the median college graduate workers earn about $60 \%$ higher salary than that of secondary school leavers (Yubilianto, 2020). The returns to education attainment in Nigeria are also indicated in the studies of Babatunde (2008); Ibekwe (2010); and Fadipe et al. (2014). Based on the theories and empirical evidence, this study agrees that there is, a positive relationship between employment and education which reduces that probability that the individual or household is below poverty level.

Estimating the standard returns to education, average returns to girls' education, average returns to household heads' education, and reasons for different returns to different disciplines are among the most common research areas of empirical studies in economics. However, the question on whose educational attainment effects household income seems to have been crowded out by the quest to estimate the average return on education attainment. This study, therefore, seeks to contribute to existing literature by explaining the effect of education attainment of the household head and that of the most educated member on household income. In addition, it examines the effect of including education attainment of household head and that of the most educated member of the household in the same household-level income function.

\section{Method}

The study was carried out in Ogoni, a rural community, in River State of Nigeria. Ogoni community (also known as Ogoniland) is made up of many dialects which can be grouped into four Khana, Gokana, Eleme and Ogoi. Ogoniland became popular given that it was among the first places where oil was found in a commercial quantity in Nigeria; Shell began drilling in Ogoniland in 1958 (Nest, 1991). Ogoni community is situated in an area of 1,000 square kilometers in the southeastern border of Niger Delta River in the South-South region of Nigeria. Ogoniland consist of four local government areas (LGA) namely Eleme, Gokana, Khana, and Tai as depicted in Figure 1. According to the National Bureau of Statistics [NBS] (2014), the 2013 total number of regular households in Ogoni community is estimated to be around 210,724. The distribution of these households according to local government areas is presented in Table 1. 


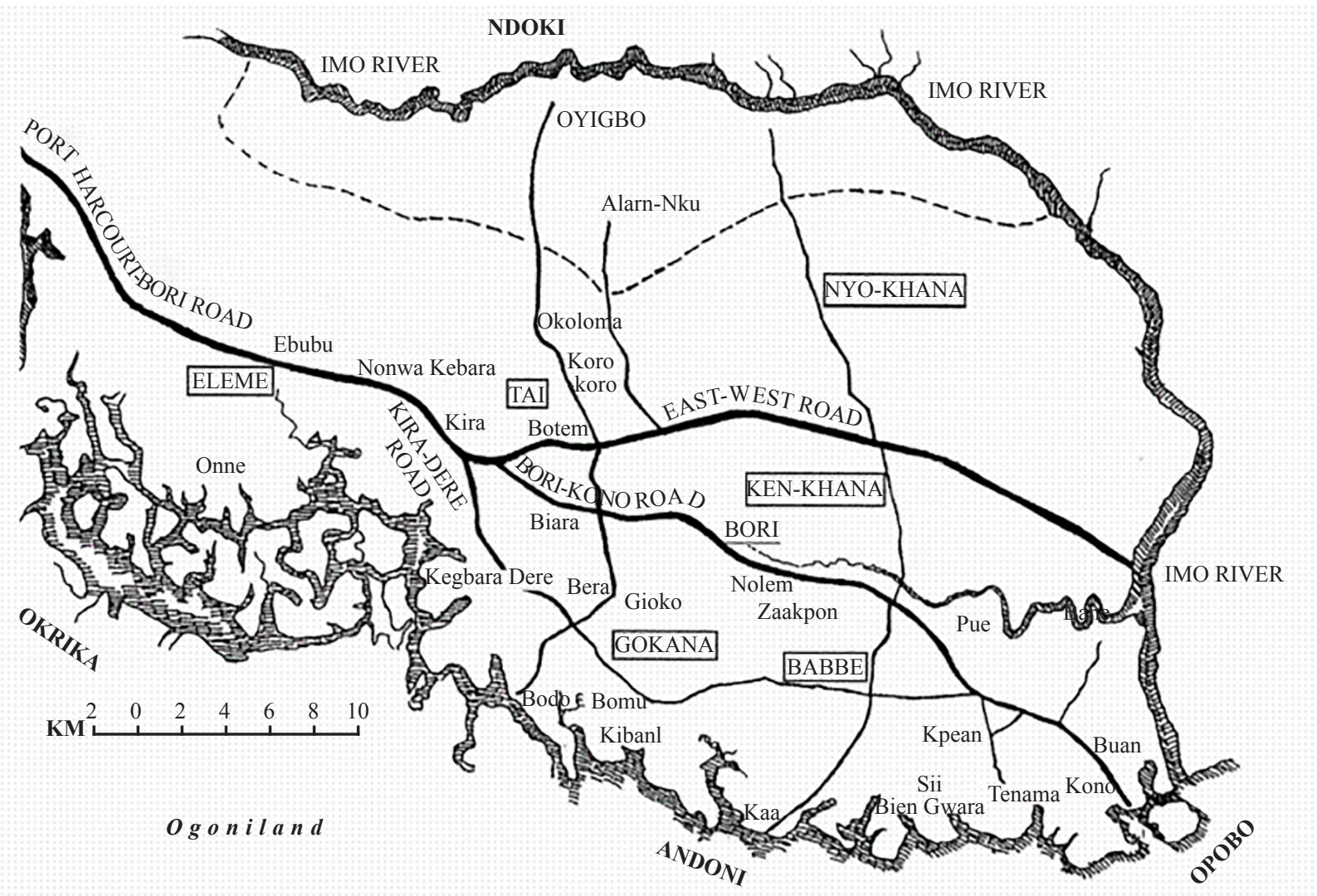

Source: (MITEE reserch foundation $\odot 1995$ )

Figure 1. Map of Ogoni land

Table 1. Number of inhabitants by LGA (2013 estimate)

\begin{tabular}{ccc}
\hline LGA & Inhabitants & Regular Households \\
\hline Eleme & 223,686 & 48,362 \\
Gokana & 268,149 & 57,976 \\
Khana & 344,772 & 74,542 \\
Tai & 138,037 & 29,844 \\
Total Population & 974,644 & 210,724 \\
\hline
\end{tabular}

Source: (National Bureau of Statistics [NBS], 2014)

For this study, a cross-sectional survey was carried out in Ogoni community between December 2013 and January 2014. Households were used as the sample frame. Sample size was calculated using the formula specified by Yamane (1967).

$$
s=\frac{N}{1+N\left(e^{2}\right)}
$$

where $s=$ required sample size, $N=$ the population size, and $e=$ the degree of accuracy expressed as a proportion (.05). Given the total number of households, a sample size of 400 was selected for the study. The sample size was distributed 
in proportion to number of households in each local government area-Eleme (92), Gokana (110), Khana (141), and Tai (57). The specified sample size from each local government was randomly selected from a sample frame household list obtained from Nigerian Population Commission (NPC). Microsoft-Excel Random in-between tool was used in the selected of participating households; however, selected households that were not willing to participate were replaced using same random method.

The face and content validities of the questionnaire were ascertained by some experts in economics department, Faculty of Social Sciences, University of Nigeria, Nsukka, and an Ogoni indigene (a government employed Physician in Ogoni community). A pilot study of 30 households randomly selected in Tai local government area, which is one of the local government areas of the study, was used to determine the reliability of the questionnaire. Their responses were examined using Split-half reliability index-coefficient alpha (Cronbach, 1951). The range of coefficient alpha is from 0 to 1: the closer it is to 1 , the more reliable the questionnaire. A reliability co-efficient alpha of 0.83 was obtained for the questionnaire. This was considered high enough for the study.

\subsection{Mean difference test (t-statistic)}

The two core exogenous variables considered in this study are:

Highest education attainment of Household head (ET)

Highest education attainment of the most educated member of household (ET2)

As a result, it was expedient to test the null hypothesis that the true mean difference, between these two core variables (ET and TE2), is zero. To do this, the under-stated procedure was followed (Moore et al., 2009):

1. Obtain the difference $\left(d_{i}=E T_{i}-E T 2_{i}\right)$ between the two observations on each pair.

2. Obtain the mean difference, $\bar{d}$

3. Obtain the standard deviation of the differences $\left(S_{d}\right)$, and obtain the standard error of the mean difference using: $\bar{d}=\frac{s_{d}}{\sqrt{n}}$

4. Obtain the $t$-statistic using $t=\frac{\bar{d}}{S E(d)}$

Note: $t$-statistic follows a $t$-distribution with degrees of freedom $n-1$.

5. Use $p$-value, null hypothesis that the true mean difference is zero is rejected of the estimated $p$-value is greater than $\alpha$; where $\alpha$ in this study is $5 \%$.

\subsection{Conceptual framework}

Conceptual framework used in this study was adapted from Janjua and Kamal (2011). As represented in Figure 2, education attainment has both direct and indirect effects on income.



Figure 2. Conceptual framework depicting links between education and household income Source: Adapted from Janjua and Kamal (2011) 
Among the direct effects are skill acquisition and human capital development which enhance productivity leading to increase in income. On the other hand, awareness and labour mobility are two major aspects of indirect effects of education on income. As stated earlier, education attainment enhances one's capability to receive, interpret, and understand new information (Nelson \& Phelps, 1966). Awareness, therefore, enhances human health and capability leading to increase productivity and income. Similarly, mobility enhances the chances of a worker to move from lowerpaid employment to higher-paid employment.

\subsection{Ordinal logistic model}

The contribution of education to household income was estimated using ordinal logit model as stated in equation 2 (Borooah, 2001). Ordinal logit model was adopted because the household income obtained for this study was in an ordered category where income $\$ 18000$ and below was represented by $1, \$ 18100$ to $\$ 50000$ was represented by 2, in that order was shown in Table 2.

$$
y^{*}=\sum \alpha_{k} x_{k}+\mu_{k}
$$

where $y^{*}$ represents an unobserved continuous tendency behind the observed ordinal response (rating). $X_{k}$ are the exogenous variables, while the $\alpha_{k}$ are the associated parameters, and $\mu_{k}$ captures stochastic variation. It is assumed to be distributed logistically. Equation 3 shows the relating of the unobserved $y^{*}$ to $Y$ through a series of "cut points".

$$
\left.\begin{array}{l}
Y=1 \text { if } y^{*} \leq \delta_{1} \\
Y=2 \text { if } \delta_{1}<y^{*} \leq \delta_{2} \\
\cdots \\
Y=j \text { if } \delta_{j-1}<y^{*}
\end{array}\right\}
$$

where $Y$ is the rating, and the $\delta$ 's represent thresholds of $y^{*}$ that delineate the categories of the ordered response variable. The threshold parameters are constrained to be positive where each one is greater than the previous-ordered responses. The first parameter $\delta_{1}$ is normalized to 0 so that one less parameter has to be estimated. That is not a problem because the scale of the latent variable is arbitrary (Borooah, 2001). In this study, $Y$ (household income) is restricted to a fivepoint Likert item-capturing different ordered categories of income levels (Table 2). The independent variables used in the estimation are also described in Table 2.

\begin{tabular}{|c|c|c|}
\hline Variable Code & Type & Description \\
\hline Income & Quantitative & $\begin{array}{c}\text { Household income ( } 18000 \text { and Below }=1, \$ 18100-\$ 50000=2, \$ 50100-\$ 100000=3, \\
\$ 100100-\$ 250000=4,>250,000=5)\end{array}$ \\
\hline ET & Quantitative & $\begin{array}{c}\text { Education attainment of household head (no formal edu. }=0, \mathrm{FSLC}=1, \mathrm{SSCE}=2, \mathrm{OND}=3, \mathrm{~B} . \mathrm{Sc} . \\
\text { and above }=4)\end{array}$ \\
\hline ET2 & Quantitative & $\begin{array}{l}\text { Education attainment of the most educated member of household (no formal edu. }=0, \mathrm{FSLC}=1, \mathrm{SSCE}=2 \text {, } \\
\qquad \mathrm{OND}=3 \text {, B.Sc. and above }=4 \text { ) }\end{array}$ \\
\hline HHhead_gender & Dummy & Gender of the household head $($ male $=1$, female $=0)$ \\
\hline Hhsize & Numeric & Total number of the members of the household \\
\hline Hhagric & Dummy & Household involved in agricultural production $($ Involved $=1$, Not involved $=0$ ) \\
\hline Socialcap & Quantitative & Household social capital measured by level of trust $($ very low $=1$, low $=2$, average $=3$, high $=4$, ery high $=5$ ) \\
\hline Electricity & Quantitative & Electricity supply (very low $=1$, low $=2$, average $=3$, high $=4$, very high $=5$ ) \\
\hline
\end{tabular}

Table 2. Definition of variables 
Using equation 2, the following three models (equations 4-6) were estimated with STATA 13:

income $=\mathrm{f}(\mathrm{ET}$, HHhead_gender, Hhsize, Hhagric, socialcap, electricity $)$

income $=\mathrm{f}(\mathrm{ET} 2$, HHhead_gender, Hhsize, Hhagric, socialcap, electricity $)$

income $=\mathrm{f}(\mathrm{ET}, \mathrm{ET} 2$, HHhead_gender, Hhsize, Hhagric, socialcap, electricity $)$

\section{Discussion of results}

Table 3. Basic socio-economic characteristics of the households

\begin{tabular}{|c|c|c|c|c|c|}
\hline \multicolumn{2}{|c|}{ Variable } & \multicolumn{2}{|c|}{ Frequency } & \multicolumn{2}{|c|}{ Percentage } \\
\hline \multicolumn{6}{|c|}{ Gender of Household head } \\
\hline \multicolumn{2}{|c|}{ Male } & \multicolumn{2}{|c|}{278} & \multicolumn{2}{|c|}{69.5} \\
\hline \multicolumn{2}{|c|}{ Female } & \multicolumn{2}{|c|}{122} & \multicolumn{2}{|c|}{30.5} \\
\hline \multicolumn{2}{|c|}{ Total } & \multicolumn{2}{|c|}{400} & \multicolumn{2}{|c|}{100.0} \\
\hline \multicolumn{6}{|c|}{ Average monthly household income in naira ( $)^{*}$} \\
\hline \multicolumn{2}{|c|}{$\$ 18,000$ and Below } & \multicolumn{2}{|c|}{161} & \multicolumn{2}{|c|}{40.5} \\
\hline \multicolumn{2}{|c|}{$¥ 18,100-\cong 50,000$} & \multicolumn{2}{|c|}{100} & \multicolumn{2}{|c|}{25.1} \\
\hline \multicolumn{2}{|c|}{$\$ 50,100-\$ 100,000$} & \multicolumn{2}{|c|}{68} & \multicolumn{2}{|c|}{17.1} \\
\hline \multicolumn{2}{|c|}{$¥ 100,100-\approx 250,000$} & \multicolumn{2}{|c|}{35} & \multicolumn{2}{|c|}{8.8} \\
\hline \multicolumn{2}{|c|}{ Above $¥ 250,000$} & \multicolumn{2}{|c|}{34} & \multicolumn{2}{|c|}{8.5} \\
\hline \multicolumn{2}{|c|}{ Total } & & & & \\
\hline & & of Elect & in commu & & \\
\hline & & & & & \\
\hline & & & & & \\
\hline & & & & & \\
\hline & & & & & \\
\hline & & & & & \\
\hline & & & & & \\
\hline & & ld invol & lltural prod & & \\
\hline & & & & & \\
\hline & & & & & \\
\hline & & & & & \\
\hline Social capital & by le & $\begin{array}{l}\text { ommun } \\
\text { articipa }\end{array}$ & $\begin{array}{l}\text { tion with i } \\
\text { cal activitie }\end{array}$ & onship & ig money \\
\hline & & & & & \\
\hline & & & & & \\
\hline & & & & & \\
\hline & & & & & \\
\hline & & & & & \\
\hline & & & & & \\
\hline & & & & & \\
\hline Variable & Obs. & Mean & Std. Dev. & Min & Max \\
\hline Household size & 400 & 6 & 2.42638 & 1 & 16 \\
\hline
\end{tabular}

*Average Exchange rate in December 2013 and January 2014 was $1 \$=\$ 157.28$ (CBN, 2014) 
Majority (69.5\%) of the surveyed households had male heads. As of the time of this study, official minimum wage was 18,000 naira (\$) with an exchange rate of $1 \$=157.28$. This informed the classification of the average monthly income. Households with average monthly income of the maximum of 18,000 naira had the highest proportion (40.5\%) among the surveyed households (Table 3 ). This is closely followed by the households with $\$ 18,100-\$ 50,000$ naira (25.1\%). Only $8.8 \%$ and $8.5 \%$ had average monthly income of $\$ 100,100-\$ 250,000$ naira and above $\$ 250,000$ naira respectively (Table 3 ). The result showed that majority (73.4\%) of the households did not rate availability of electricity above average. Only $26.6 \%$ rated it above average. Table 3 also indicated that most of the surveyed households (75.6) were involved in agricultural activities. Only $1.8 \%$ and $6.4 \%$ indicated that social capital was very high and high respectively; $20.1 \%$ and $24.7 \%$ indicated that it was very low and low respectively; while, the rest indicated it was average (Table 3).

The first thing to observe in Table 4 is that the total number of responses obtained for the household heads (399) and the most educated members of the households (390) are not equal. This discrepancy, due to missing responses, was taken care of in the calculation of the paired $t$-test (mean difference) which used 389 paired responses, and in the estimation of the ordinal logit models which used between 373 and 380 responses. We considered $93 \%$ (373 responses) of the sample size reliable enough for estimation of the parameters.

Furthermore, Table 4 indicates that majority of the household heads $(60.7 \%)$ and the most educated member of the household (74.3\%) had at least Ordinary National Diploma. About $26 \%$ and $20 \%$ of the household heads and the most educated member of the household had secondary education respectively. Only $3.8 \%$ of the household heads had no formal education; $10.3 \%$ had primary education. Similarly, only $4.9 \%$ the most educated member of the household had primary education. Generally, only $0.8 \%$ of the surveyed households indicated that no member had completed primary education.

Table 4. Highest academic qualification of Household head and the most educated member of household

\begin{tabular}{ccc}
\hline & $\begin{array}{c}\text { Highest academic qualification of } \\
\text { Household head }\end{array}$ & $\begin{array}{c}\text { Highest academic qualification of } \\
\text { thest educated member of household }\end{array}$ \\
\hline Education Level & Frequency (\%) & Frequency (\%) \\
Primary education & $15(3.8)$ & $3(0.8)$ \\
Secondary education & $41(10.3)$ & $19(4.9)$ \\
OND/Diploma/Diploma equivalent & $91(22.8)$ & $78(20.0)$ \\
HND/ First Degree/ Post Graduate degree & $147(37.9)$ & $194(49.6)$ \\
Total & $399(100)$ & $390(100)$
\end{tabular}

Note: OND = Ordinary National Diploma, HND = Higher National Diploma

The discrepancy between the distributions of education attainment of the household heads and that of the most educated member of households was examined to ascertain if it is significant. Table 5 shows the result of the test hypothesis that the true mean difference, between ET and TE2, is zero. The $t$-test result (Table 5) shows strong evidence against the null hypothesis and in support of the alternative hypothesis that the true mean difference is not equal to zero $(\mathrm{p}<0.001)$. We conclude that, on average, the education attainment of the most educated member of households is significantly higher $($ with mean difference $=0.37789)$ than that of the household heads $(p<0.001)$.

Pair-wise correlation among the variables is presented in Table 6. The highest correlation co-efficient $(0.6808)$ was observed between education attainment of the household heads (ET) and education attainment of the most educated member of households (ET2) which is significant at 5 per cent. In other words, though these two variables are significantly different, they have fairly strong positive correlation (Table 6). According to Gujarati (2004), high correlation between two variables indicates collinearity. 
Table 5. Paired t-test (mean difference) between education attainment of the household heads (ET) and education attainment of the most educated member of households (ET2)

\begin{tabular}{|c|c|c|c|c|c|c|}
\hline Variable & Obs. & Mean & Std. Err. & Std. Dev. & \multicolumn{2}{|c|}{ [95\% Conf. Interval] } \\
\hline ET & 389 & 2.796915 & 0.058524 & 1.15428 & 2.681851 & 2.91198 \\
\hline ET2 & 389 & 3.174807 & 0.048981 & 0.966065 & 3.078505 & 3.271109 \\
\hline Diff & 389 & -0.37789 & 0.043336 & 0.854717 & -0.46309 & -0.29269 \\
\hline \multicolumn{4}{|c|}{$\operatorname{mean}($ diff $)=\operatorname{mean}(\mathrm{ET}-\mathrm{ET} 2)$} & \multicolumn{2}{|c|}{$\mathrm{t}=-8.7201$} & \\
\hline \multicolumn{3}{|c|}{ Ho: mean $($ diff $)=0$} & & \multicolumn{3}{|c|}{ Degrees of freedom $=388$} \\
\hline \multicolumn{2}{|c|}{ Ha: mean (diff) $<0$} & \multicolumn{2}{|c|}{ Ha: mean(diff) $!=0$} & \multicolumn{3}{|c|}{ Ha: mean $($ diff $)>0$} \\
\hline \multicolumn{2}{|c|}{$\operatorname{Pr}(\mathrm{T}<\mathrm{t})=0.0000$} & \multicolumn{2}{|c|}{$\operatorname{Pr}(\mathrm{T}>\mathrm{t})=0$} & \multicolumn{3}{|c|}{$\operatorname{Pr}(\mathrm{T}>\mathrm{t})=1.0000$} \\
\hline
\end{tabular}

Table 6. Correlation matrix

\begin{tabular}{cccccccc}
\hline- & Income & ET & ET2 & HHhead_gender & Electricity & Hhagric & Socialcap \\
\hline Income & 1 & - & - & - & - & - & - \\
ET & $0.237^{*}$ & 1 & - & - & - & - & - \\
ET2 & $0.321^{*}$ & $0.688^{*}$ & 1 & - & - & - & - \\
HHhead_gender & $0.102^{*}$ & -0.027 & -0.008 & 1 & - & - & - \\
Electricity & $0.355^{*}$ & 0.080 & $0.142^{*}$ & -0.035 & $0.157^{*}$ & 1 & - \\
Hhagric & $0.314^{*}$ & $0.146^{*}$ & 0.088 & 0.073 & $-0.127^{*}$ & $-0.268^{*}$ & 1 \\
Socialcap & $-0.212^{*}$ & 0.081 & 0.063 & -0.032 & - & - \\
\hline
\end{tabular}

*significant at $5 \%$

Following the established difference between the distributions of education attainment of the household heads and that of the most educated member of households as well as high correlation among these two variables, we estimated the following three models:

1. Regress household income against the exogenous variables including education attainment of the household heads (ET);

2. Regress household income against the exogenous variables including education attainment of the most educated member of households (ET2);

3. Regress household income against the exogenous variables including both education attainment of the household heads (ET) and education attainment of the most educated member of households (ET2).

The results of the estimated models are presented in Table 7. Model 1 shows that education attainment of the household heads (ET) influences household incomes significantly $(\mathrm{p}<0.001)$ and Model 2 shows that education attainment of the most educated member of households (ET2) also influences household incomes significantly ( $p$ $<0.001$ ). However, Model 3, which includes both education attainment of the household heads (ET) and education attainment of the most educated member of households (ET2) as exogenous variables, suggests that the parameter estimate of education attainment of the household heads (ET) was biased by the presence of education attainment of the most educated member of households (ET2). Hence, unlike in Model 1, education attainment of the household heads (ET) had no influence $(p>0.05)$ in Model 3. The biased parameter estimate of education attainment of the household head (ET) in Model 3 could have been caused by the high correlation between the variable (ET) and education attainment of the most educated member of households (ET2). Therefore, Models 1 and 2 should be preferred to Model 3. Thus, only models 1 and 2 are further discussed below. 
Table 7. Ordered logistic regression (Dependent variable $=$ Household income)

\begin{tabular}{|c|c|c|c|c|c|c|}
\hline & \multicolumn{2}{|c|}{ Model 1: With household head (ET) } & \multicolumn{2}{|c|}{$\begin{array}{l}\text { Model 2: With most educated household } \\
\text { member (ET2) }\end{array}$} & \multicolumn{2}{|c|}{$\begin{array}{l}\text { Model 3: With household head (ET) and } \\
\text { most educated household member (ET2) }\end{array}$} \\
\hline Variable & \multicolumn{2}{|c|}{ Coef. } & \multicolumn{2}{|c|}{ Coef. } & \multicolumn{2}{|c|}{ Coef. } \\
\hline ET & $0.410^{* * *}$ & $(0.000)$ & - & - & 0.084 & 0.478 \\
\hline ET2 & - & - & $0.700^{* * *}$ & $(0.000)$ & $0.626^{* * *}$ & $(0.000)$ \\
\hline HHhead_gender & $0.454 * *$ & $(0.036)$ & $0.487 * *$ & $(0.029)$ & $0.507 * *$ & $(0.024)$ \\
\hline Hhsize & $0.134 * * *$ & $(0.001)$ & $0.087 * *$ & $(0.037)$ & $0.093 * *$ & $(0.032)$ \\
\hline Hhagric & $0.946^{* * *}$ & $(0.000)$ & $1.041 * * *$ & $(0.000)$ & $1.024 * * *$ & $(0.000)$ \\
\hline Socialcap & $-0.344 * * *$ & $(0.002)$ & $-0.357 * * *$ & $(0.001)$ & $-0.371 * * *$ & $(0.001)$ \\
\hline Electricity & $0.451^{* * *}$ & $(0.000)$ & $0.451 * * *$ & $(0.000)$ & $0.449^{* * *}$ & $(0.000)$ \\
\hline /cut1 & \multicolumn{2}{|c|}{3.394} & \multicolumn{2}{|c|}{4.334} & \multicolumn{2}{|c|}{4.321} \\
\hline /cut2 & \multicolumn{2}{|c|}{4.587} & \multicolumn{2}{|c|}{5.562} & \multicolumn{2}{|c|}{5.554} \\
\hline /cut3 & \multicolumn{2}{|c|}{5.675} & \multicolumn{2}{|c|}{6.656} & \multicolumn{2}{|c|}{6.636} \\
\hline /cut4 & \multicolumn{2}{|c|}{6.634} & \multicolumn{2}{|c|}{7.632} & \multicolumn{2}{|c|}{7.614} \\
\hline & $\begin{array}{r}\text { Numbe } \\
\text { LR cl } \\
\text { Pro } \\
\text { Log lik } \\
\text { Pseuc }\end{array}$ & $\begin{array}{l}=380 \\
13.9 \\
0 \\
=-488 \\
105\end{array}$ & $\begin{array}{r}\text { Numbe } \\
\text { LR ch } \\
\text { Pro } \\
\text { Log lik } \\
\text { Pseu }\end{array}$ & $\begin{array}{l}=374 \\
2.75 \\
0 \\
=-469 \\
124\end{array}$ & $\begin{array}{r}\text { Numb } \\
\text { LR c } \\
\text { Pr } \\
\text { Log } 1 \\
\text { Pse }\end{array}$ & $\begin{array}{l}=373 \\
2.92 \\
0 \\
-468 \\
125\end{array}$ \\
\hline
\end{tabular}

Notes: Figures in parentheses are p-values

$*, * *$ and $* * *$ denote significance at $\mathrm{P}<0.1, \mathrm{P}<0.05$ and $\mathrm{P}<0.01$ probability levels, respectively

The odd ratio of education attainment of household head in Model 1 and that of the most educated member of the household in Model 2 are 0.41 and 0.7 respectively. These coefficients (ET in Model 1 and ET2 in Model 2) are positive and significant. This indicates that both the education attainment of household head and the education attainment of the most educated member of the household play significant role towards the enhancement of household income, especially in Ogoniland. Table 5 indicates that education attainment of the most educated member of the household is significantly higher (with mean difference $=0.37789$ ) than that of the household heads. The regression result in Table 7 and the $t$-statistic test in Table 5, suggest that a household with higher level of education is most likely to earn higher than household with lower level of education-ceteris paribus. This result supports with human capital and signalling theories and other empirical studies (Psacharopoulos \& Patrinos, 2018; Bartik et al., 2018; Babatunde, 2008; Ibekwe, 2010).

On the other hand, as expected, virtually all other exogenous variables (gender of household head, household size, households in agriculture, and electricity supply) showed positive and significant $(\mathrm{p}<0.05)$ influence on household income apart from social capital which showed significant $(\mathrm{p}<0.05)$ but negative influence on household income in all the models. These results (Table 7) suggest that the higher the trust Ogoni people have on prompt assistance from their social networks (social capital) the less they strive for cash income enhancement.

\subsection{Conclusion and policy implications}

We can draw two methodological conclusions from this study with regard to the estimation of the influence of education attainment on household income. First, from the data collection point of view, education attainment surveys can collect information either on the education attainment of household head or the education attainment of the most educated member of the household, or on both. Second, when estimating the effects of these two variables (as exogenous variables) on household-level income, they should not be used together in the same model to avoid biased parameter estimate due to collinearity. These findings agree with Weir (1999) that in modeling education attainment in 
household-level income functions, different measures of education may be used; however, the education attainment of household head and the education attainment of the most educated member of the household should not be used together in the same household-income level function even when significant difference exists between the two exogenous variables. Nevertheless, this conclusion many differ where the years of education is used as against categorized levels of education (see Table 2). Furthermore, in agreement with relevant theories and previous empirical studies (Psacharopoulos \& Patrinos, 2018; Bartik et al., 2018; Babatunde, 2008; Ibekwe, 2010). The ordinal logistic regression results confirm that the influence of education attainment on household income in Ogoniland is positive and significant $(p<0.001)$. The study, therefore, concludes that any policy or intervention on raising education attainment of, at least, a household member is an effective way of influencing household income in Ogoniland, and perhaps, in other communities of the world. The policy implications of the findings of this study is that Government should endeavour to increase budgetary allocation to the education sector and ensure effective utilization of such fund. Government can also partner with the private sector, especially privately owned schools, to enhance the affordability of quality education. In addition, households should give priority to investment on the education of its members.

\subsection{Limitations}

The authors acknowledge a major limitation of this study which is recommended for further study. The data used in this study did not provide information on how many household heads were the most educated members of their respective households. The possible endogeneity bias in such situation should be captured in future estimation. For instance, in a model developed by Zhang et al. (2019), personal attributes (such as education, age, gender) of the member with the highest education were controlled for in the estimation of household income generation (total, agriculture and non-agriculture). This is one of the possible ways of handling situations that require differentiating personal attributes regarding the head versus the member with the highest education attainment. Furthermore, following the conceptual framework of this study, another suggestion for future study is to estimate the direct and indirect effects separately to better understand the mechanisms on how education helps generate income.

\section{Acknowledgements}

The authors appreciate the valuable inputs from the anonymous reviewers and the editorial team of Regional Economic Development Research.

\section{Reference}

Babatunde, R. O. (2008). Income inequality in rural nigeria: Evidence from farming households survey data. Australian Journal of Basic and Applied Sciences, 2(1), 134-140.

Bartik, Timothy J., \& Brad H. (2018). Degrees of poverty: The relationship between family income background and the returns to education. Upjohn Institute Working Paper, 18-284. Kalamazoo, MI: W.E. Upjohn Institute for Employment Research. https://doi.org/10.17848/wp18-284

Blanden, J., Buscha, F., Sturgis, P., \& Urwin, P. (2012). Measuring the earnings returns to lifelong learning in the UK. Economics of Education Review, 31, 501-514.

Borooah, V. K. (2001). Logit and probit: Ordered and multinomial models. Series on Quantitative Applications in the Social Sciences, 138. Sage Publications, London. https://doi.org/10.4135/9781412984829

Bourguignon, F. (2005). Equity and economic growth: Permanent questions and charging answers, prepared for human development report. United National Development Programme (UNDP).

CBN. (2014). Monthly average exchange rates of the Naira (Naira Per Unit of Foreign Currency). Central Bank of Nigeria. https://www.cbn.gov.ng/rates/exrate.asp?year=2014

Cronbach, L. J. (1951). Coefficient alpha and the internal structure of tests. Psychometrika, 16, 297-334.

de Baldini, R., Maúna, S., \& Ponczek, V. (2011). The effects of adult literacy on earnings and employment. Economics of Education Review, 30(4), 755-764.

Devereux, P. J., \& Fan, W. (2011). Earnings returns to the British education expansion. Economics of Education Review, 
30(6), 1153-1166.

Dickson, M., \& Harmon, C. (2011). Economic returns to education: What we know, what we don't know, and where we are going-some brief pointers. Economics of Education Review, 30(6), 1118-1122.

Dickson, M., \& Smith, S. (2011). What determines the return to education: An extra year or a hurdle cleared? Economics of Education Review, 30(6), 1167-1176.

Evan, D. P., Günther, F., \& Wafaie, F. (2015). Returns to education in developing countries: Evidence from the living standards and measurement study surveys. Economics of Education Review, 49, 69-90.

Fadipe, A. E. A., Adenuga, A. H., \& Lawal, A. (2014). Analysis of income determinants among rural households in Kwara State, Nigeria. Trakia Journal of Sciences, 4, 400-404.

Frank, M. F., \& Tobias, J. M. B. (2013). The returns to education for opportunity entrepreneurs, necessity entrepreneurs, and paid employees. Economics of Education Review, 37, 66-84.

Ganegodage, K. R., \& Rambaldi, A. N. (2011). The impact of education investment on Sri Lankan economic growth. Economics of Education Review, 30(6), 1491-1502

Gujarati, D. (2004). Basic econometrics (3rd ed.). New York: McGraw-Hill International Editions.

Hanushek, E. A. (2013). Economic growth in developing countries: The role of human capital. Economics of Education Review, 37, 204-212.

Hanushek, E. A., \& Wößmann, L. (2007). The role of school improvement in economic development. World Bank Policy Research Working Paper, 352, 4122.

Ibekwe, U. C. (2010). Determinants of income among farm households in orlu agricultural zone of Imo State, Nigeria. Report and Opinion, 2(8), 32-35.

Jamison, D. T., \& Lau, L. J. (1982). Farmer education and farm efficiency. Washington D.C.: World Bank.

Janjua, P. Z., \& Kamal, U. A. (2011). The role of education and income in poverty alleviation: A cross-country analysis. The Lahore Journal of Economics, 16(1), 143-172.

Jehovaness, A. (2010). Determinants of rural income in Tanzania: An empirical approach. Research Report 10/4, Deres Salaam, REPOA.

Jolliffe, D. (1997). Whose education matters in the determination of household income: Evidence from a developing country. Food consumption and nutrition division. Discussion Paper, 39, 1-38.

Leigh, A., \& Ryan, C. (2008). Estimating returns to education using different natural experiment techniques. Economics of Education Review, 27(2), 149-160.

Moore, D. S., McCabe, G. P., \& Craig, B. A. (2009). Introduction to the Practice of Statistics (6th ed.). New York: W. H. Freeman and Company.

NBS. (2014). 2013 Statistical Report on Women and Men in Nigeria. Nigeria: National Bureau of Statistics.

Nelson, R. R., \& Edmund, S. P. (1966). Investment in humans, technological diffusion, and economic growth. American Economic Review, 56, 69-75.

NEST. (1991). Nigeria's threatened environment: A national profile. Nigeria Ibadan: Nigerian Environmental Study/ Action Team.

Park, S. (2011). Returning to school for higher returns. Economics of Education Review, 30(6), 1215-1228.

Psacharopoulos G., \& Patrinos H.A. (2018). Returns to investment in education: A decennial review of the global literature. Policy Research Working Paper 8402, World Bank Group-Education Global Practice.

Roberts, L. (1988). On the mechanics of economic development. Journal of Monetary Economics, 22, 3-42.

Tsai, W., Liu, J., Chou, S., \& Thornton, R. (2009). Does educational expansion encourage female workforce participation? A study of the 1968 reform in Taiwan. Economics of Education Review, 28(6), 750-758.

Tuyen, T. Q. (2015). Socio-economic determinants of household income among ethnic minorities in the North-West Mountains, Vietnam. Croatian Economic Survey, 17(1), 139-159.

Van Vu, H. (2020). The impact of education on household income in rural vietnam. International Journal of Financial Studies, 8(1), 11. https://doi.org/10.3390/ijfs8010011

Wanka F. A. (2014). The impact of educational attainment on household poverty in South Africa: A case study of limpopo province. A mini-thesis submitted in partial fulfilment of the requirement for the degree of Master of Economics in the Department of Economics, University of the Western Cape.

Wanka F. A., \& Rena R. (2019). The impact of educational attainment on household poverty in South Africa: A case study of Limpopo province. African Journal of Science, Technology, Innovation and Development, 11(5), 597-609. https://doi.org/10.1080/20421338.2018.1557368

Weir, S. (1999). The effects of education on farmer productivity in rural ethiopia. Centre for the Study of African Economies, Department of Economics, University of Oxford, WPS99-7, 1-50.

Wolla S. A., \& Sullivan J. (2017, January 03). Education, income, and wealth. Page One Economics. https://research. 
stlouisfed.org/publications/page1-econ/2017/01/03/education-income-and-wealth/

Yamane, T. (1967). Statistics: An introductory analysis (2nd ed.). New York: Harper and Row.

Yubilianto. (2020). Return to education and financial value of investment in higher education in Indonesia. Journal of Economic Structures, 9, 17. https://doi.org/10.1186/s40008-020-00193-6

Zhang, Q., Bilsborrow R. E., Song C., \& Tao S. (2019). Rural household income distribution and inequality in China: Effects of payments for ecosystem services policies and other factors. Ecological Economics: The Journal of the International Society for Ecological Economics, 160, 114-127. https://doi.org/10.1016/j.ecolecon.2019.02.019 